\title{
Influence of Maneuvering Singa Feeder at Bukit Siguntang Substation on Power Shrinkage Using ETAP 19.0.1
}

\author{
Anton Firmansyah, Destra Andika Pratama, M. Raihan Ismail
}

\begin{abstract}
- the need for electricity supply in the community and industry is increasing over time, it is necessary to provide energy and a safe and reliable electricity distribution system, which can minimize blackouts so as to maintain customer satisfaction. One way to increase reliability and minimize blackouts is through a network maneuvering process. This study calculates the magnitude of the power loss value on the power line in the feeder that maneuvers the Singa feeder with the aim of knowing the value of power loss that occurs during the maneuver so that network maneuvering activities on the Singa feeder become more optimal. The Singa feeder can be maneuvered by two feeders, namely the Kijang feeder and the Kancil feeder. Based on SPLN 72: 1987, the standard maximum value for medium-voltage
\end{abstract}

Keywords: Bukit Siguntang, Substation, Maneuver, Feeder, Losses, Power, Shrinkage, ETAP

\section{INTRODUCTION}

$\mathrm{F}$ or an effort to maintain the availability of reliable and sustainable electricity supply, PT. PLN (Persero) performs network maneuvering activities on the distribution system. A distribution network maneuver is a series of activities that alter the normal operation of the network due to disruption or network work that requires a power outage, so that the power outage area is reduced and the distribution of electrical power remains in optimal condition [1].

Network maneuvering is an important step in the operation of an electric power distribution system. Because of the importance of this activity, the distribution operations controller (dispatcher) must be able to act quickly and precisely in maneuvering the network. The consideration of dispatcher when maneuvering the distribution network is to consider the maximum load capacity and protection equipment on the refiner and shrink that will arise as a result of the maneuvers carried out [2].

Bukit Siguntang Substation has 3 transformers with details, 1). 30 MVA transformers which supplies 4 feeders, 2). 30 MVA transformers which supplies 5 feeders and 3). 30 MVA transformers which supplies 5 feeders. The Singa feeder is supplied by transformer 330 MVA and can be maneuvered to 3 backup feeders in the event of a disturbance that causes transformer 3 to not be able to supply electricity, namely the kancil feeder, the kijang feeder and the dayung feeder. When maneuvering a network, dispatchers do not really consider how much power loss the line will be maneuvering.

\section{RiseARCH Methode}

\subsection{Research Data and Supporting Data}

The research method is a method that has been systematically and scientifically determined to observe and analyze a problem which produces a conclusion that is useful for finding, developing and testing knowledge. The things discussed in the research method are as follows: This research was carried out in March 2021 - July 2021 completed at PT. PLN (Persero) UP3 Palembang and UIWS2JB. Research variables the research variable is the power flow contained in the electric power system at the Bukit Siguntang Substation calculation and using the ETAP Power Station 19.0.1 software. In this research process, the tools and materials used are: Laptop Hardware and ETAP 19.0.1 software, besides that, a feeder is also needed at the Bukit Siguntang Substation, namely: 1). Data on the capacity and load of the transformer at the Singa Feeder, Kijang and Kancil. 2). Conductor type data and conductor resistance value data. 3). Data Map source Feeder and 4). One Line Feeder Diagram.

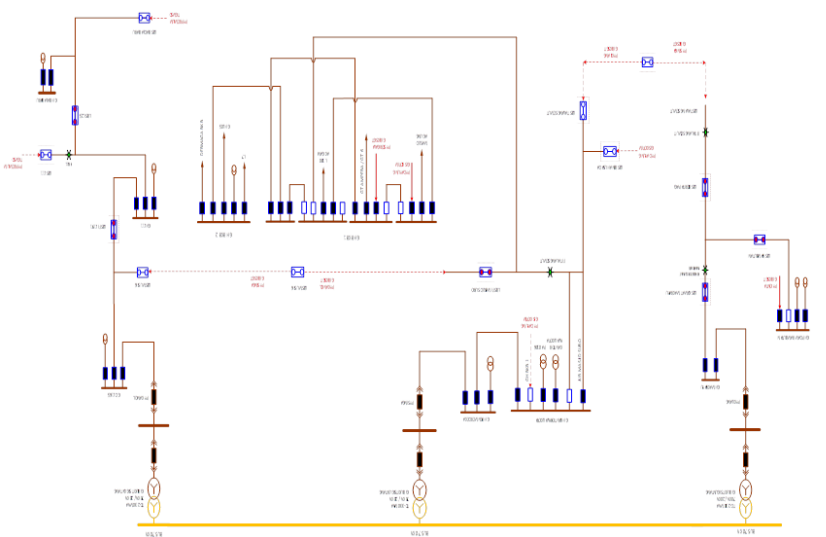

Figure 1. Singa, Kijang and Kancil Singel Line Diagram Source : PT. PLN (Persero) UP3 Palembang, 2021

\subsection{Lenght and Conductor Type Feeder on Bukit Siguntang Substation}

In high-voltage overhead lines (SUTT), the distance between the tower/pole and others are located far apart so a conductor with better ability to transmit electrical energy. 
Wire type the conductor used in the transmission line is copper with conductivity $100 \%$ (Cu 100\%), copper with a conductivity of $97.5 \%(\mathrm{Cu} 97.5 \%)$, or aluminum with a conductivity of $61 \%$ ( $\mathrm{Al} 61 \%$ ). The following are the types of aluminum conductors:

Table 1. Lenght and diameter conduktor on Feeder

\begin{tabular}{|c|c|c|c|c|c|c|}
\hline \multirow{3}{*}{$\begin{array}{l}\text { Conductor } \\
\text { Type }\end{array}$} & \multicolumn{6}{|c|}{ Feeder's } \\
\hline & \multicolumn{2}{|c|}{ Singa } & \multicolumn{2}{|c|}{ Kijang } & \multicolumn{2}{|c|}{ Kancil } \\
\hline & $\begin{array}{c}\text { Conductor } \\
\text { Diamter } \\
(\mathrm{mm}) \\
\end{array}$ & $\begin{array}{l}\text { Lenght } \\
(\mathrm{km})\end{array}$ & $\begin{array}{c}\text { Conductor } \\
\text { Diamter } \\
(\mathrm{mm}) \\
\end{array}$ & $\begin{array}{l}\text { Lenght } \\
(\mathrm{km})\end{array}$ & $\begin{array}{c}\text { Conductor } \\
\text { Diamter } \\
(\mathrm{mm})\end{array}$ & $\begin{array}{l}\text { Lenght } \\
(\mathrm{km})\end{array}$ \\
\hline $\begin{array}{c}\text { NA2XSEYFGbY } \\
\text { (AL) }\end{array}$ & 240 & 4.3 & 240 & 0.42 & 240 & 0,346 \\
\hline $\begin{array}{c}\text { NA2XSEYFGbY } \\
\text { (AL) }\end{array}$ & 240 & 0.56 & - & - & - & - \\
\hline A3CS & 150 & 2.8 & 150 & 3,2 & 150 & 3,7 \\
\hline A3C & 150 & 0.45 & 150 & 2,6 & 150 & 2,06 \\
\hline $\begin{array}{c}\text { NA2XSEYFGbY } \\
\text { (AL) }\end{array}$ & 240 & 4.3 & - & - & - & - \\
\hline
\end{tabular}

Source : PT. PLN (Persero) UP3 Palembang, 2021

\subsection{Feeder Load Type Feeder on Bukit Siguntang Substation}

The load on the Bukit Siguntang substation feeder can be seen in the following table

Table 2. Feeder Load on Bukit Siguntang Substation

\begin{tabular}{ccc}
\hline \multirow{2}{*}{ Feeder } & \multicolumn{2}{c}{ Feeder Load } \\
\cline { 2 - 3 } & $\begin{array}{c}\text { Current } \\
\text { (Ampere) }\end{array}$ & $\begin{array}{c}\text { Power } \\
(\mathrm{MW})\end{array}$ \\
\hline \hline Kijang & $\mathbf{1 1 1 , 8}$ & 3,48 \\
Kancil & 97,7 & 3,04 \\
Singa & 56 & 1,74 \\
\hline
\end{tabular}

Source : PT. PLN (Persero) UP3 Palembang, 2021

Table 3. Transformer Distribution Load on feeder Bukit Siguntang Substation

\begin{tabular}{cccccc}
\hline \hline Kijang & \multicolumn{2}{c}{ Kancil } & \multicolumn{2}{c}{ Singa } \\
\hline \hline $\begin{array}{c}\text { Distribution } \\
\text { Transformer } \\
\text { (Code) }\end{array}$ & $\begin{array}{c}\text { Load } \\
\text { (kVA) }\end{array}$ & $\begin{array}{c}\text { Distribution } \\
\text { Transformer } \\
\text { (Code) }\end{array}$ & $\begin{array}{c}\text { Load } \\
\text { (kVA) }\end{array}$ & $\begin{array}{c}\text { Distribution } \\
\text { Transformer } \\
\text { (Code) }\end{array}$ & $\begin{array}{c}\text { Load } \\
\text { (kVA) }\end{array}$ \\
\hline \hline PAX101 & 150 & PA0008 & 318 & PA0006 & 128 \\
PAX018 & 250 & PA0011 & 59 & PA0007 & 147 \\
\hline PAX088 & 75 & PA0016 & 48 & PA0188 & 224 \\
\hline PA0101 & 217 & PA0017 & 160 & PA0192 & 195 \\
\hline PA0115 & 171 & PA0048 & 197 & PA0295 & 107 \\
PA0157 & 229 & PA0124 & 151 & PA0544 & 124 \\
\hline PA0180 & 89 & PA0190 & 138 & PA0557 & 226 \\
\hline PA0212 & 47 & PA0329 & 31 & PA0613 & 19 \\
\hline PA0229 & 250 & PA0338 & 30 & PA0717 & 44 \\
\hline PA0287 & 93 & PA0422 & 0 & PA0915 & 81 \\
\hline PA0340 & 135 & PA0483 & 114 & PA0916 & 29 \\
\hline PA0438 & 127 & PA0508 & 107 & PA0028 & 196 \\
\hline PA0445 & 102 & PA0509 & 123 & PA0464 & 16 \\
\hline PA0459 & 49 & PA0563 & 111 & PA0478 & 45 \\
\hline PA0501 & 88 & PA0584 & 21 & PA0641 & 65 \\
\hline PA0564 & 59 & PA0619 & 131 & PA0870 & 50 \\
\hline PA0623 & 7 & PA0650 & 20 & PAX122 & 315 \\
\hline PA0653 & 226 & PA0732 & 78 & PAX114 & 12 \\
\hline PA0684 & 58 & PA0834 & 82 & - & - \\
\hline PA0725 & 75 & PA0838 & 21 & - & - \\
\hline PA0772 & 63 & PA0910 & 32 & - & - \\
\hline PA0024 & 137 & PAX036 & 200 & - & - \\
\hline PA0030 & 98 & PAX021 & 1000 & - & - \\
\hline PA0032 & 136 & PAX029 & 100 & - & - \\
\hline PA0041 & 34 & PAX020 & 150 & - & - \\
\hline & & & & & \\
\hline
\end{tabular}

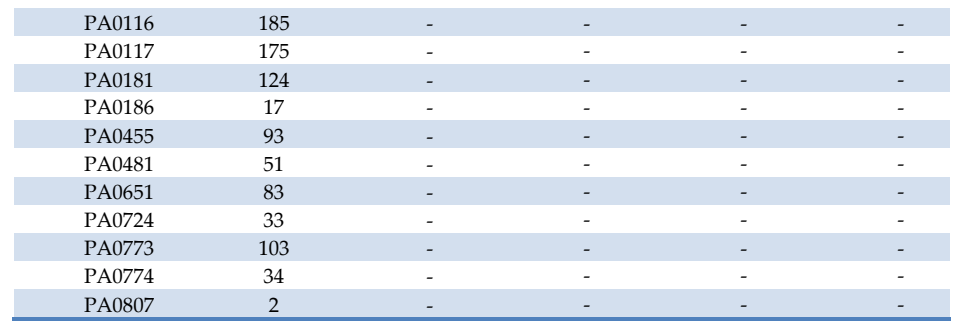

Source : PT. PLN (Persero) UP3 Palembang, 2021

\subsection{Map Source Feeder on Bukit Siguntang Substation}

Data on the length and type of feeders and distribution substations of the Kijang, Kancil and Singa feeder can be measured through map source. Starting from the substation to the final load and voltage of the Kijang feeder can be measured accurately because it is based on GPS mapping.

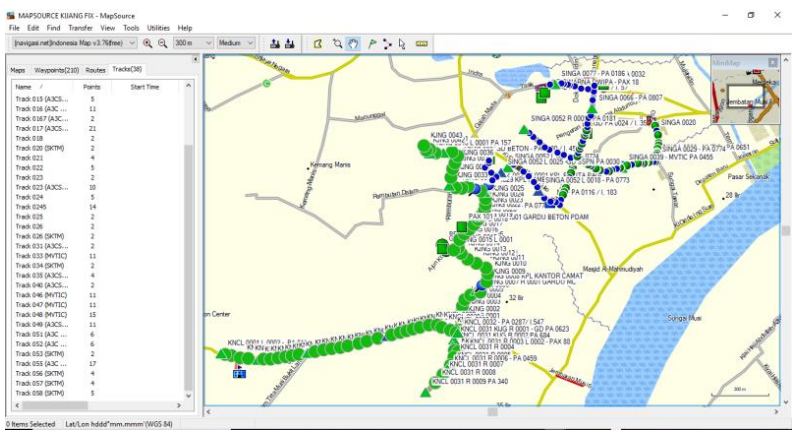

a). Kijang Feeder

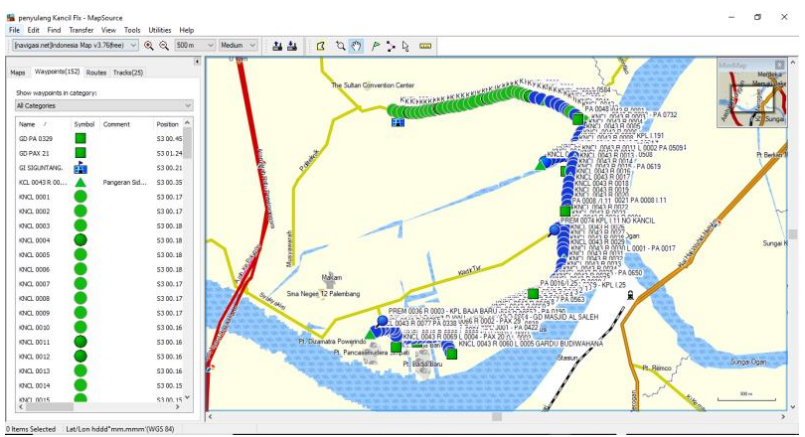

b). Kancil Feeder

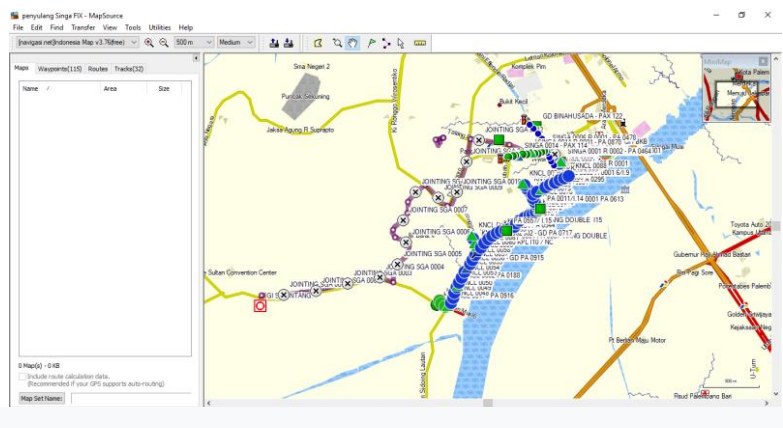

c). Singa Feeder

Figure 2. Single Line Diagram Feeder on Bukit Siguntang Source : PT. PLN (Persero) UP3 Palembang, 2021 


\section{RESULT AND DISCUSSION \\ 3.1 Line Resistance Calculation}

The calculated resistance is a temperature of $75^{\circ}$, assuming the temperature at peak load, and at a temperature of $20^{\circ}$ for low temperatures. Calculation using:

$\frac{\mathrm{R} 2}{\mathrm{R} 1}=\frac{\mathrm{T}+\mathrm{t}_{2}}{\mathrm{~T}+\mathrm{t}_{1}}$

- NA2XSEYBY $240 \mathrm{~mm}$

$\frac{R 2}{0,125}=\frac{228+75^{\circ} \mathrm{C}}{228+20^{\circ} \mathrm{C}}$

$248 R_{2}=37,875$

$R_{2}=0,152 \Omega / \mathrm{km}$

- A3C-S $150 \mathrm{~mm}$

$\frac{R 2}{0,225}=\frac{228+75^{\circ} \mathrm{C}}{228+20^{\circ} \mathrm{C}}$

$248 R_{2}=68,175$

$R_{2}=0,275 \Omega / \mathrm{km}$

- A3C-S $150 \mathrm{~mm}$

$$
\begin{aligned}
& \frac{R 2}{0,225}=\frac{228+75^{\circ} \mathrm{C}}{228+20^{\circ} \mathrm{C}} \\
& 248 R_{2}=68,175 \\
& R_{2}=0,275 \Omega / \mathrm{km}
\end{aligned}
$$

\subsection{LOSSES POWER IN NORMAL CONDITION}

The calculation of the all feeder power loss value for the feeder that maneuvers uses $\mathrm{Pz}=3 . \mathrm{I}^{2}$.R.L, the peak load is obtained from table 2. Length is obtained from table 1, and the resistance value is obtained calculation. Calculations can be done using the ETAP application to get the accuracy of the power loss values that occur in the field. In this report the author uses the ETAP 19.0.1 application.

- $\quad$ Power Losses at Kijang Feeder

NA2XSEYBY $240 \mathrm{~mm}^{2}$

$P_{\Sigma}=3 . I^{2} \cdot R \cdot L$

$P_{z}=3 \times 111.8^{2} \times 0,152 \times 0,42$

$P_{z}=2393 \mathrm{~W}$

AAAC $150 \mathrm{~mm}^{2}$

$P_{z}=3 . I^{2} \cdot R \cdot L$

$P_{z}=3 \times 111.8^{2} \times 0,275 \times 2,6$

$P_{z}=26810 \mathrm{~W}$

AAACS $150 \mathrm{~mm}^{2}$

$P_{z}=3 . I^{2} \cdot R \cdot L$

$P_{z}=3 \times 111.8^{2} \times 0,275 \times 3,3$

$P_{z}=30029 \mathrm{~W}$

Total Power Losses on Kijang Feeder

$P_{\text {Total }}=2393+26810+30029$

$P_{\text {Total }}=59232 \mathrm{~W}$

If the amount of power loss has been obtained, then the

power received is $P_{R}=P-P_{z}$, then the value of the percentage $(\%)$ of power loss is $\Delta \mathrm{P}=\frac{\mathrm{P}_{\text {Lnxx }}}{\mathrm{P}} \times 100 \%$,

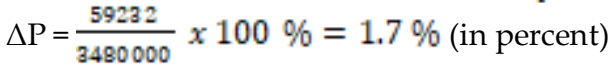

From the data obtained through map source and the SLD of the Kijang, the load flow of the Kijang feeder can be simulated feeder Decrease the power of the Kijang feeder using the ETAP application as follows:

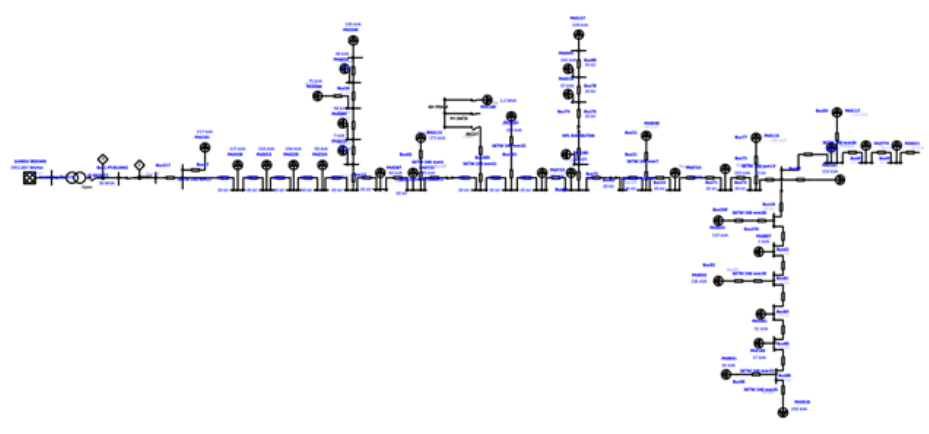

Figure 3. Single Line Diagram Kijang Feeder with ETAP

- Kancil Feeder Power Losses

NA2XSEYBY $240 \mathrm{~mm}^{2}$

$P_{\Omega}=3 . I^{2} \cdot R \cdot L$

$P_{z}=3 \times 97,7^{2} \times 0,152 \times 0,346$

$P_{z}=1506 \mathrm{~W}$

AAAC $150 \mathrm{~mm}^{2}$

$P_{z}=3 . I^{2} \cdot R_{x} L$

$P_{z}=3 \times 97,7^{2} \times 0,275 \times 2,06$

$P_{z}=16222 \mathrm{~W}$

AAACS $150 \mathrm{~mm}^{2}$

$P_{z}=3 . I^{2} \cdot R_{x} L$

$P_{z}=3 \times 97,7^{2} \times 0,275 \times 3,7$

$P_{\Sigma}=29136 \mathrm{~W}$

Total Power Losses on Kancil Feeder

$P_{\text {Total }}=1506+16222+29136$

$P_{\text {Total }}=46864 \mathrm{~W}$

If the amount of power loss has been obtained, then the power received is $P_{R}=P-P_{z}$, then the value of the percentage $(\%)$ of power loss is $\Delta P=\frac{P_{\text {Lmsx }}}{P} \times 100 \%$, $\Delta \mathrm{P}=\frac{46864}{3040000} \times 100 \%=1.5 \%$ (in percent)

From the data obtained through map source and the SLD of the Kancil, the load flow of the Kancil feeder can be simulated feeder Decrease the power of the kancil feeder using the ETAP application as follows: 


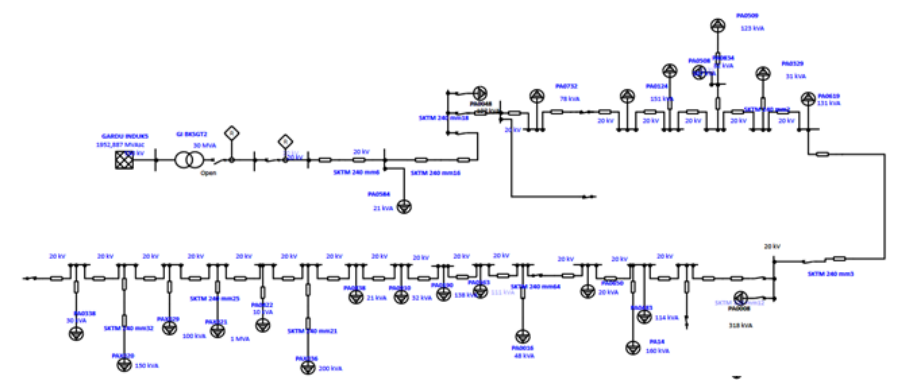

Figure 4. Single Line Diagram Kancil Feeder

- $\quad$ Singa Feeder Power Losses

NA2XSEYBY $240 \mathrm{~mm}^{2}$

$P_{\Sigma}=3 . I^{2} \cdot R \cdot L$

$P_{\Omega}=3 \times 59,8^{2} \times 0,152 \times 0,56$

$P_{z}=913 \mathrm{~W}$

$$
\begin{aligned}
& \text { AAAC } 150 \mathrm{~mm}^{2} \\
& P_{z}=3 . I^{2} \cdot R \cdot L \\
& P_{z}=3 \times 59,8^{2} \times 0,275 \times 0,45 \\
& P_{z}=1327 \mathrm{~W}
\end{aligned}
$$

$$
\begin{aligned}
& \text { AAACS } 150 \mathrm{~mm}^{2} \\
& P_{\Sigma}=3 . I^{2} \cdot R \cdot L \\
& P_{\Omega}=3 \times 59,8^{2} \times 0,275 \times 2,8 \\
& P_{\Omega}=8260 \mathrm{~W}
\end{aligned}
$$

Total Power Losses on Kancil Feeder

$$
\begin{aligned}
& P_{\text {Total }}=913+1327+8260 \\
& P_{\text {Total }}=10500 \mathrm{~W}
\end{aligned}
$$

If the amount of power loss has been obtained, then the power received is $P_{R}=P-P_{z}$, then the value of the percentage (\%) of power loss is $\Delta \mathrm{P}=\frac{\mathrm{P}_{\mathrm{Lngs}}}{\mathrm{P}} \times 100 \%$, $\Delta \mathrm{P}=\frac{10500}{1860000} \times 100 \%=0.56 \%$ (in percent)

From the data obtained through map source and the SLD of the Kancil, the load flow of the Kancil feeder can be simulated feeder Decrease the power of the kancil feeder using the ETAP application as follows:

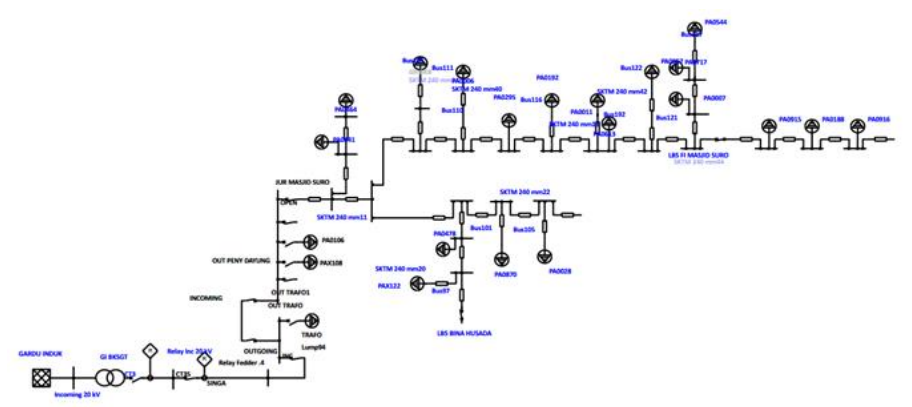

Figure 5. Single Line Diagram Singa Feeder

\subsection{Losses POWER ON MANEUVERING CONDITIONS}

Singa feeder load can be fully maneuvered to 2 feeders, simulation in this report maneuver the Singa feeder load in zone 2 after the output of Mayor subtation circuit, and simulated with the ETAP. Calculation of the power loss of the Singa feeder after being maneuvered can be done by adding up the power loss of the singa feeder and the feeder to be maneuvered, namely the kijang feeder and the kancil feeder.

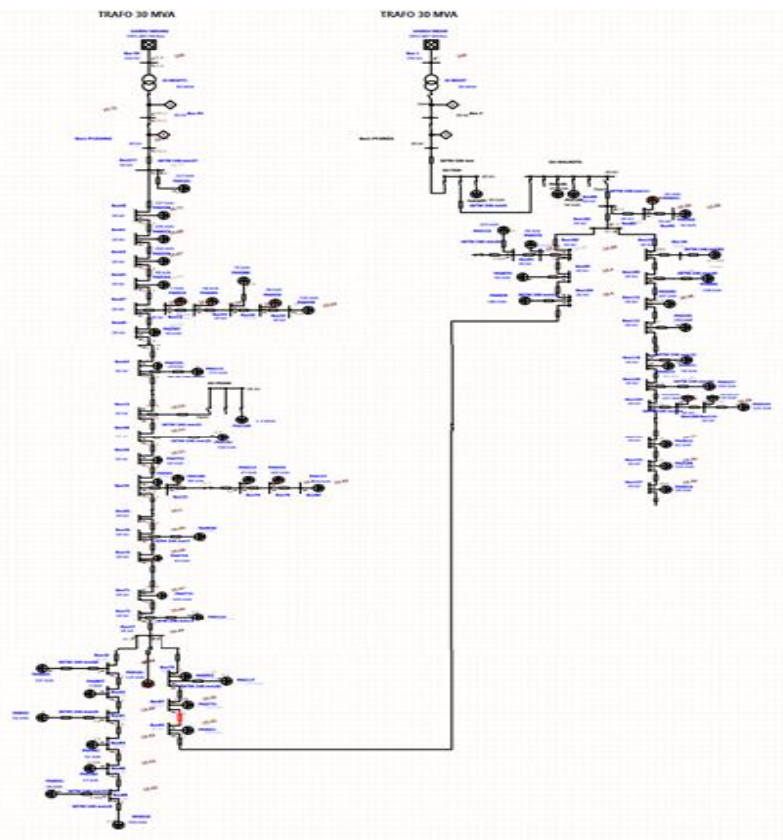

Figure 6. ETAP Simulation Maneuvering Single Line Diagram

\subsubsection{LOSSES POWER ON SINGA FEEDER MANEUVERED TO KIJANG FEEDER}

Singa Feeder loses power after being maneuvered into the Kijang feeder through the Talang Semut LBS.

$\checkmark$ Power Losses on Kijang Feeder Maneuver in Singa Feeder

Power Losess $\quad=\Delta W$ Kijang $+\Delta W$ Singa

$$
=59232+10500
$$$$
=69732 \mathrm{~W}
$$

$\Delta \mathrm{P}=\frac{69732}{5340000} \times 100 \%=1,3 \%$

\subsubsection{LOSSES POWER ON SINGA FEEDER MANEUVERED TO KANCIL FEEDER}

Singa Feeder loses power after being maneuvered into the Kancil feeder through the Musi 6 LBS.

$\checkmark$ Power Losses on Kijang Feeder Maneuver in Kancil Feeder

Power Losess $\quad=\Delta \mathrm{W}$ Kancil $+\Delta \mathrm{W}$ Singa

$=46864+10500$

$=57364 \mathrm{~W}$

\section{4 Main Priority ANALysis}

Based on the results of calculations and simulations using ETAP obtained the following data : 
Table 4. Power Losses Normal Conditions

\begin{tabular}{c|cccc|}
\multicolumn{2}{c}{ Power Losses } & \multicolumn{2}{c}{ Power Losses $(\%)$} \\
\hline Feeder & $\begin{array}{c}\text { Calculate } \\
(\mathrm{W})\end{array}$ & $\begin{array}{c}\text { ETAP } \\
\text { Simulation } \\
(\mathrm{W})\end{array}$ & $\begin{array}{c}\text { Calculate } \\
(\mathrm{W})\end{array}$ & $\begin{array}{c}\text { ETAP } \\
\text { Simulation } \\
(\mathrm{W})\end{array}$ \\
\hline Kijang & 59232 & 14500 & $1.7 \%$ & $0.416 \%$ \\
Kancil & 46864 & 23600 & $1.5 \%$ & $0.776 \%$ \\
Singa & 10500 & 1600 & $0.56 \%$ & $0.086 \%$ \\
\cline { 2 - 5 } & & &
\end{tabular}

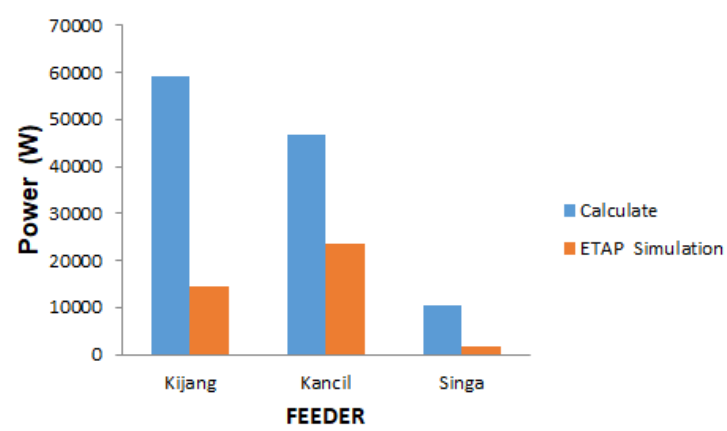

Figure 8. Calculate Power Losses at Maeuver Condition

Table 5. Power Losses Maneuver Conditions

\begin{tabular}{c|cccc|}
\multirow{2}{*}{ Feeder } & \multicolumn{2}{c}{ Power Losses } & \multicolumn{2}{c}{ Power Losses (\%) } \\
\cline { 2 - 5 } & $\begin{array}{c}\text { Calculate } \\
(\mathrm{W})\end{array}$ & $\begin{array}{c}\text { ETAP } \\
\text { Simulation } \\
(\mathrm{W})\end{array}$ & $\begin{array}{c}\text { Calculate } \\
(\mathrm{W})\end{array}$ & $\begin{array}{c}\text { ETAP } \\
\text { Simulation } \\
(\mathrm{W})\end{array}$ \\
\hline Singa - Kijang & 69732 & 49500 & $1.3 \%$ & $0.923 \%$ \\
Singa - Kancil & 57364 & 50400 & $1.17 \%$ & $1 \%$
\end{tabular}

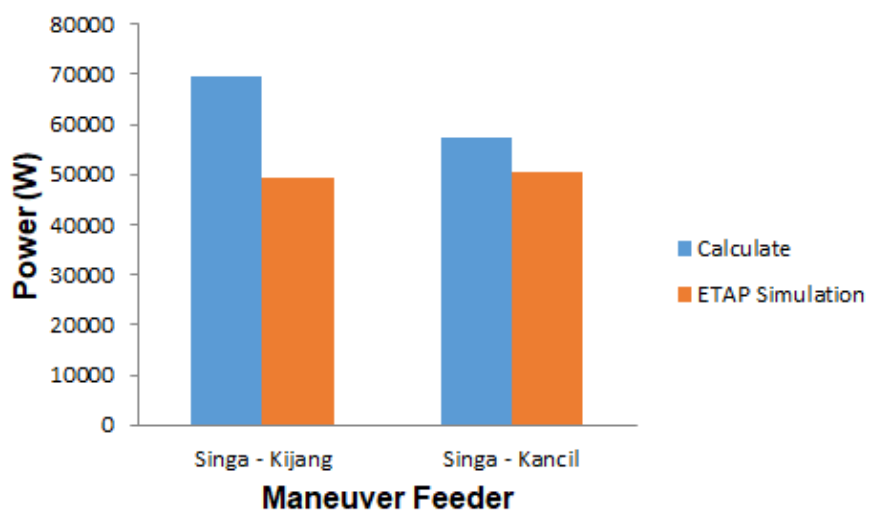

Figure 9. ETAP Simulation Power Losses at Maeuver Condition

From the table and graph above, it is known that the Kijang feeder is the most optimal feeder based on the shrinkage value after being maneuvered using the ETAP simulation. However, there are differences from manual calculations and using ETAP simulations where the manual calculation priority scale shows that the Kancil feeder is more optimal in the shrinkage value. This is because in manual calculations the load is considered to be at the end of the channel so that the value of the current flowing at the base of the channel to the end of the channel remains the same. Meanwhile, using ETAP simulation, the load can be accurately simulated the position of the load with respect to the conductor, which causes the current flowing at the base of the channel to the end of the channel to be different so that the calculations carried out can be more accurate as in real conditions.

This difference is seen more clearly in the shrinkage value of the Kancil feeder which is larger than the Kijang feeder. Where, in the ETAP simulation the Kancil feeder has a conductor length of $1.37 \mathrm{~km}$ which is located at the base of the network which has no load while the Kijang feeder only has the longest conductor of $400 \mathrm{~m}$ at the base of the network where the current flowing at the base of the network is greater than in the middle. and the end of the network

The difference is also seen in the value of shrinkage during maneuvering. The position of the maneuvering point on the Talang Semut LBS, located at the end of the Kijang feeder resulted in an increase in the current value in almost the entire Kijang feeder channel and then it was divided into the Singa feeder channel. When compared to the Kancil feeder, whose maneuvering point is at the base of the feeder, the increase in current value only occurs at the base of the Kancil feeder channel, then it is divided into the Singa feeder channel where only the base of the Kancil feeder experiences an increase in current value.

The value of shrinkage on the Kijang and Kancil feeders in normal conditions and in a state of maneuver does not exceed the standard set by SPLN 72: 1987 which is below 2\% so that the order of priority patterns for maneuvering the Singa feeder is as follows: 1). Kijang Feeder, 2). Kancil Feeder

\section{Conculsion}

The two feeders who maneuver the singa feeder, namely the kijang feeder and the kancil feeder, have a power loss value that is still within normal limits and in accordance with the standards set by SPLN 72: 1987, which is below $2 \%$, so it is no longer necessary to improve the power loss value of the feeder.

The priority scale for maneuvering the Singa feeder based on the power loss value is the Kijang feeder because the Kijang feeder power loss value is better than the mouse Kijang feeder. From the results of manual calculations and ETAP simulations, the final results in looking for power losses are differences in results and the differences are quite visible. Finding the value of power loss using ETAP simulation, the 
load can be accurately simulated the position of the load against the conductor so that the calculations carried out can be more accurate like real conditions. While the manual calculation of the load is considered to be at the end of the channel. This means that manual calculations can be used to find power losses, only the results obtained are less efficient and less accurate in accordance with the reality that occurs in the field.

\section{ACKNOWLEDGMENT}

The author would like to thank the Manager, Supervisor, and all employees of PT PLN (Persero) UP3 Palembang who have helped in this research.

\section{REFERENCES}

[1] Alif Karnandi Ode, Moethia Faridha "Pengaruh Manuver Jaringan Distribusi $20 \mathrm{Kv}$ Terhadap Indeks Keandalan Penyulang BT07 Batulicin" ode I EEICT (Electric, Electronic, Instrumentation, Control, Telecommunication) (uniska-bjm.ac.id), 2020

[2] Aj Firdaus, "Analisa Beban Section Untuk Menentukan Alternatif Manuver Jaringan Distribusi 20 Kv Penyulang Brg3 PT. PLN (Persero) Unit Layanan Salatia", - Jtet (Jurnal Teknik Elektro Terapan), Jurnal.Polines.Ac.Id 2013

[3] Arismunandar, Artono. 2004. Teknik Tenaga Listrik Jilid II. Jakarta : PT. Pradnya Paramita

[4] Cekdin, Cekmas. 2013. Transmisi Daya Listrik. Yogyakarta : Andi

[5] Kadir, Abdul (2000). Distribusi Dan Utilisasi Tenaga Listrik. Jakarta: UI - Press.

[6] L. Multa and R. P. Aridani, "Modul Pelatihan ETAP," Modul Pelatih. ETAP, 2013.

[7] Ratno Wibowo, Winayu, dkk. 2010. Buku I Kriteria Disain Enjinering Konstruksi Jaringan Distribusi Tenaga Listrik. Jakarta Selatan: PT.PLN (Persero)

[8] Sarimun, Wahyudi. 2016. Proteksi Sistem Distribusi Tenaga Listrik Edisi Kedua. Depok : Garamond.

[9] Suswanto, Daman. 2009. "Sistem Distribusi Tenaga Listrik".Padang : Erlangga

[10] Standar Perusahaan Listrik Negara (SPLN) 41-8. 1981. Hantaran Aluminium Campuran. Jakarta : Departemen Pertambangan dan Energi.

[11] Standar Perusahaan Listrik Negara (SPLN) 41-10. 1991. Syarat Penghantar. Jakarta Selatan : Departemen Pertambangan dan Energi

[12] Standar Perusahaan Listrik Negara (SPLN) 52-3. 1983. Pola Pengaman Sistem. Jakarta Selatan : Departemen Pertambangan dan Energi.

[13] Standar Perusahaan Listrik Negara (SPLN) 72. 1991. Spesifikasi desain urntuk Jaringan Tegangan Menengah (JTM) dan Jaringan Tegangan Rendah (JTR) Jakarta Selatan : Departemen Pertambangan dan Energi
[14] Stevenson, William D. 2000. Analisa Sistem Tenaga Listrik. Jakarta : Erlangga

[15] Zuhal, (1995). Dasar Teknik Tenaga Listrik dan Elektronika Daya. Jakarta : PT Gramedia Pustaka Utama. 